\title{
Sistem Kontrol Torsi pada Motor DC
}

\author{
Arifin Wahid Ibrahim ${ }^{* 1}$, Triyogatama Wahyu Widodo ${ }^{2}$, Tri Wahyu Supardi ${ }^{3}$ \\ ${ }^{1}$ Prodi Elektronika dan Instrumentasi, Jurusan Ilmu Komputer dan Elektronika, FMIPA \\ 2,3 Jurusan Ilmu Komputer dan Elektronika, FMIPA UGM \\ email: *1arifinwahid@gmail.com, ${ }^{2}$ yogatama@ugm.ac.id, twsupardi@ugm.ac.id
}

\begin{abstract}
Abstrak
Penggunaan motor DC di dunia industri sangat penting. Kecepatan dan torsi motor DC sangat mempengaruhi kualitas dan kuantitas produk yang dihasilkan. Untuk itu, diperlukan sistem kontrol motor DC yang dapat diatur kecepatan dan torsinya. Banyak pelaku industri mengeluhkan kerusakan pada motor DC disebakan beban yang diangkut motor melebihi kemampuan torsi motornya. Berdasarkan permasalahan tersebut dibuatlah sistem kontrol torsi motor DC.

Sistem kontrol torsi dibuat dengan cara mengatur arus armaturnya pada motor DC penguat terpisah dengan kondisi arus fieldnya tetap. Sistem kontrol torsi ini bersifat dua level yaitu, sistem kontrol kecepatan dan sistem kontrol arus sehingga sinyal keluaran sistem kontrol kecepatan akan menjadi sinyal reference arus.

Pengujian dilakukan dengan beban maksimal 3690 gram dan arus nominal sebesar 0,8 A atau torsi nominal sebesar 0,323 Nm. Hasil menunjukkan torsi efektif motor mampu diatur dengan kisaran 0,182 Nm-0,243 Nm. Diharapkan dengan harga torsi efektif yang diatur mampu menahan beban seberat apapun tanpa merusak motor tersebut.
\end{abstract}

Kata kunci- Motor DC, Kecepatan, Torsi

\begin{abstract}
The use of a DC motor in the industrialized world is very important. Speed of DC motor and torque of DC motor greatly affects quality and quantity of product. Therefore, we need control system of a DC motor that can be set speed and torque. The number of industry players complained about damage to the DC motor because transported load torque of motor exceeds capabilities of torque of DC motor. Based on these problem, we should make torque control system in DC motor.

Torque control system made by regulating armature current of DC motor separately excited with current field constant condition. Torque control system consist of speed control and current control, namely control system two level. Output signal speed control system will be the current reference signal.

Testing has been carried out with a maximum load of 3690 grams and a nominal current of $0.8 \mathrm{~A}$ or nominal torque of $0.323 \mathrm{Nm}$. The results shows the effective torque of motor is able to be set in the range of $0.182 \mathrm{Nm}-0,243 \mathrm{Nm}$. Expected to value effective of regulated torque is able to withstand infinite heavy loads without damaging the motor.
\end{abstract}

Keywords - DC Motor, Speed, Torque

\section{PENDAHULUAN}

$\mathrm{K}_{\mathrm{k}}^{\mathrm{e}}$ emajuan teknologi saat sekarang ini begitu cepat mempengaruhi seluruh aspek pada kehidupan ini. Tidak bisa dipungkiri lagi, kebutuhan akan teknologi begitu besar bila dibandingkan beberapa dekade yang lalu. Salah satu akibatnya, adanya persaingan global, terutama dibidang industri. Beberapa pelaku industri membangun atau meng-upgrade sistem di Industri untuk menghasilkan produk yang unggul dari para pesaingnya. Beberapa pelaku 
industri fokus pada kecepatan dalam menghasilkan suatu produk. Salah satu yang mempengaruhi ialah motor elektrik.

Kebutuhan akan motor elektrik merupakan kebutuhan pokok untuk memajukan suatu industri. Proyeksi kebutuhan akan motor elektrik di dunia akan meningkat 6,5\% setiap tahun. Wilayah Asia/Pasifik yang memiliki penjualan terbesar. Data ini menunjukkan bahwa motor elektrik, salah satunya motor DC sangat berperan penting dalam kecepatan produksi dan kualitas. Namun, seringkali dalam penggunaan motor DC di lingkungan industri mengalami kesulitan dalam hal pengaturan nilai torsi. Para peneliti juga memaparkan bahwa variabel torsi pada motor DC sulit untuk diukur sehingga mereka hanya bisa mencari estimasi variabel torsi.

Salah satunya proses penipisan baja di industri baja besar PT Krakatau Steel, khususnya divisi CTCM (Continous Tendem Cold Mill). Menurut Ibrahim, dalam proses penipisan baja pemrosesanya melalui 5 stand motor DC yang berbeda nilai kecepatan dan torsinya. Kemudian beberapa pelaku industri rumahan sering mengeluhkan motor yang terbakar karena beban berlebih yang menyebabkan torsi motor tidak mampu menahan sehingga arus listrik meningkat sehingga penambahan beban akan menaikan torsi dan arus yang nilainya sebanding.[1]

\subsection{Prinsip Motor DC Penguat Terpisah}

Motor DC penguat terpisah merupakan salah satu dari jenis motor DC yang dapat menambah kemampuan daya dan kecepatan karena memiliki fluks medan $(\Phi)$ yang dihasilkan oleh kumparan medan, yang terletak secara terpisah dan mempunyai sumber pembangkit tersendiri berupa tegangan DC sehingga jenis motor DC penguat terpisah ini sangat memungkinkan untuk dapat membangkitkan fluks medan $(\Phi)$ bila dibandingkan dengan motor DC magnet permanen. Karena motor DC penguat terpisah mempunyai fleksibilitas dalam pengontrolan.
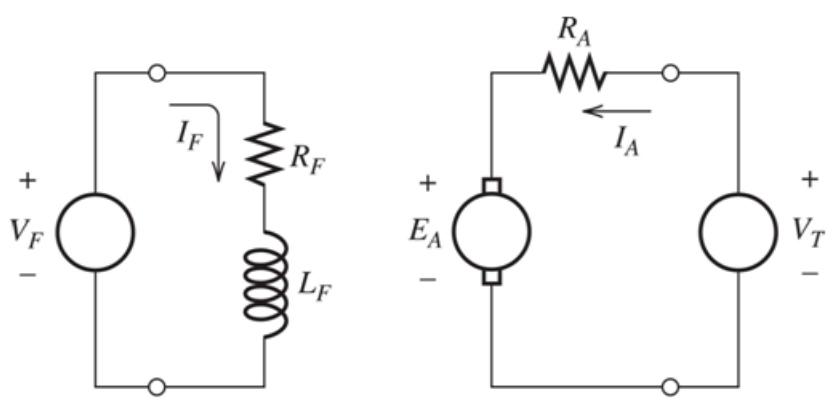

Gambar 1 Motor DC penguat terpisah

Seperti yang ditunjukan Gambar 1 merupakan gambar rangkaian motor DC penguat terpisah. Sesuai degan penamaanya, stator dan rotor memiliki penguat masing - masing. Rangkaian ini memiliki perumusan sepertii persamaan (1) berikut.

$\mathrm{V}_{\mathrm{T}}=\mathrm{E}_{\mathrm{A}}+\mathrm{I}_{\mathrm{A}} \mathrm{R}_{\mathrm{A}}$

$\mathrm{V}_{\mathrm{T}}=\mathrm{c} \mathrm{n} \Phi+\mathrm{I}_{\mathrm{A}} \mathrm{R}_{\mathrm{A}}$

Kemudian pada persamaan (2) kita bisa mendapatkan nilai kecepatan motor sehingga perumusanya menjadi seperti perumusan (3) berikut.

$\mathrm{n}=\frac{\mathrm{VT}-\mathrm{IA} \mathrm{RA}}{\mathrm{c} \cdot \Phi}$

Kemudian berdasarkan persamaan daya - daya yang bekerja pada motor didapat perumusan sebagai berikut.

$\mathrm{P}_{\text {out }}=\mathrm{P}_{\text {mekanik }}$

IJEIS Vol. 6, No. 1, April 2016 : $93-104$ 
$\mathrm{E}_{\mathrm{A}} \cdot \mathrm{I}_{\mathrm{A}}=2 \pi \mathrm{T} \cdot \mathrm{n} / 60$

Dari penurunan persamaan (4) dan (5), nilai torsii dapat ditentukan seperti persamaan (6) berikut.

$\mathrm{T}=\mathrm{k} . \Phi \cdot \mathrm{I}_{\mathrm{A}}$

Karena nilai fluks sebanding dengan nilai arus fieldnya, maka persamaanya menjadi persamaan (7) seperti berikut.

$\mathrm{T}=\mathrm{k} \cdot \mathrm{I}_{\mathrm{f}} \cdot \mathrm{I}_{\mathrm{A}}$

Berdasarkan persamaan 7, nilai torsi motor dapat ditentukan dengan perkalian antara konstanta torsi $(\mathrm{k})$, arus rotor $\left(\mathrm{I}_{\mathrm{A}}\right)$, dan arus stator $\left(\mathrm{I}_{\mathrm{f}}\right)$.

\subsection{Kontrol PI}

Karakteristik dari kontrol tersebut terdiri dari dua bagian, yaitu sebuah kontrol integral dan sebuah kontrol proporsional. Kita mengingat bahwa kontrol proporsional dapat menghilangkan error dan mempercepat respon sedangkan kontrol integral dapat menurunkan overshoot dan mempercepat steady state. Parameter dari kontrol PI sama seperti parameter kontrol proporsional dan kontrol integral.[2]

Kontroler proporsional pada dasarnya merupakan suatu penguat dengan penguatan yang dapat diatur seperti perumusan (8), diagram bloknya terlihat pada Gambar 2.

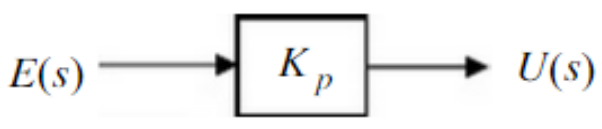

Gambar 2 Diagram blok kontroler proportional [3]

$\mathrm{Kp} . E_{(s)}=U_{(s)}$

Sedangkan Kontroler integral pada dasarnya merupakan suatu penguat dengan penguatan integral waktu seperti perumusan (9), diagram blok untuk pengendali integral pada Gambar 3.

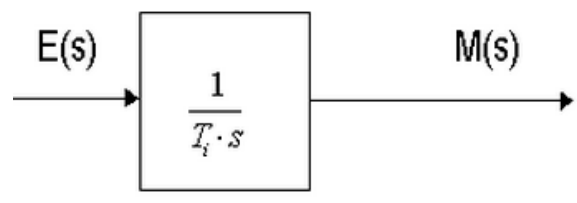

Gambar 3 Blok diagram untuk pengendali integral [4]

$\mathrm{M}(\mathrm{s})=\operatorname{Ki} \int_{0}^{\mathrm{t}} E(s) \mathrm{dt}$

\subsection{Operational Amplifier}

Dengan kata dasar "operational" yang merujuk pada penggunaanya sebagai pengoperasian matematik seperti, operasi penambahan, pengurangan, dan perkalian. Selain itu, IC ini juga berfungsi sebagai integrasi dan pembanding sinyal masukanya. Komponen jenis ini memiliki gain dan impedansi yang tinggi yang terbentuk dalam satu paket IC (Integrated Circuit). Berikut merupakan jenis - jenis rangkaian op-amp.

1. Op-amp penguat pembalik.

2. Op-amp voltage follower.

3. Op-amp pengurang/pembanding.

4. Op-amp Penjumlah. 
5. Op-amp Integrator.

\subsection{Tacho Generator}

Sensor yang sering digunakan untuk sensor kecepatan angular adalah tacho generator. Tacho generator adalah sebuah generator kecil yang membangkitkan tegangan DC ataupun tegangan AC. Dari segi eksitasi tacho generator dapat dibangkitkan dengan eksitasi dari luar atau imbas elektromagnit dari magnit permanen. Tacho generator DC dapat membangkitkan tegangan DC yang langsung dapat menghasilkan informasi kecepatan, sensitivitas tacho generator DC cukup baik terutama pada daerah kecepatan tinggi.[5]

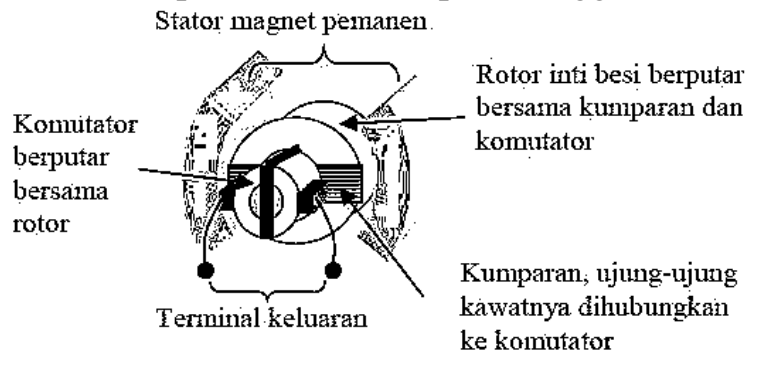

Gambar 4 Konstruksi tacho generator DC [5]

Gambar 4 menunjukkan konstruksi tacho generator DC. Tacho generator ini merupakan instrumen yang memiliki element sensing kecepatan dan hasil sinyal sudah otomatis ditransmitter menjadi sinyal tegangan

\subsection{Momen Gaya}

Momen gaya merupakan besaran yang dapat menyebabkan sebuah titik partikel berputar (berotasi). Momen gaya merupakan besaran yang dipengaruhi oleh gaya dan lengan.

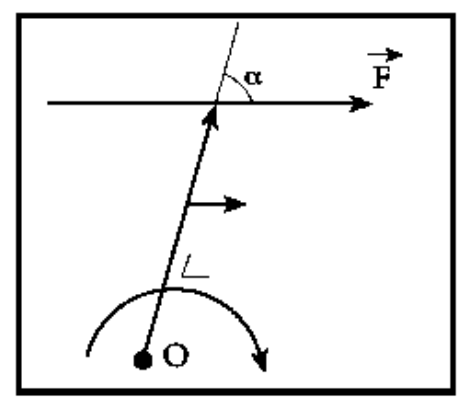

Gambar 5 Momen gaya $F$

Pada Gambar 5 menunjukkan momen gaya $\mathrm{F}$ terhadap titik $\mathrm{O}$ didefinisikan sebagai hasil kali silang antara lengan gaya $\mathrm{L}$ dan gaya $\mathrm{F}$, seperti dalam persamaan (10) berikut :

$\tau=L \cdot \sin \alpha . F$

\section{METODE PENELITIAN}

\subsection{Perancangan Sistem}

Sistem kontrol torsi ini berprinsip bahwa nilai arus motor sebanding dengan nilai torsi motor sehingga nilai torsi diatur dengan cara mengatur arus motornya. Jadi nilai referensi torsi sebanding dengan referensi arus. Dengan prinsip ini sistem kontrol torsi dibuat dalam bentuk sistem kontrol arus. Kemudian untuk menstabilkan kecepatan saat melakukan kontrol arus motor, maka arus reference dibuat dalam bentuk kontrol kecepatan. Untuk itu kita harus membuat sistem kontrol torsi dalam 2 level yaitu, kontrol kecepatan dan kontrol arus. Untuk 
lebih jelasnya kita bisa lihat pada Gambar 6 yang menjelaskan diagram blok sistem pada penelitian ini.

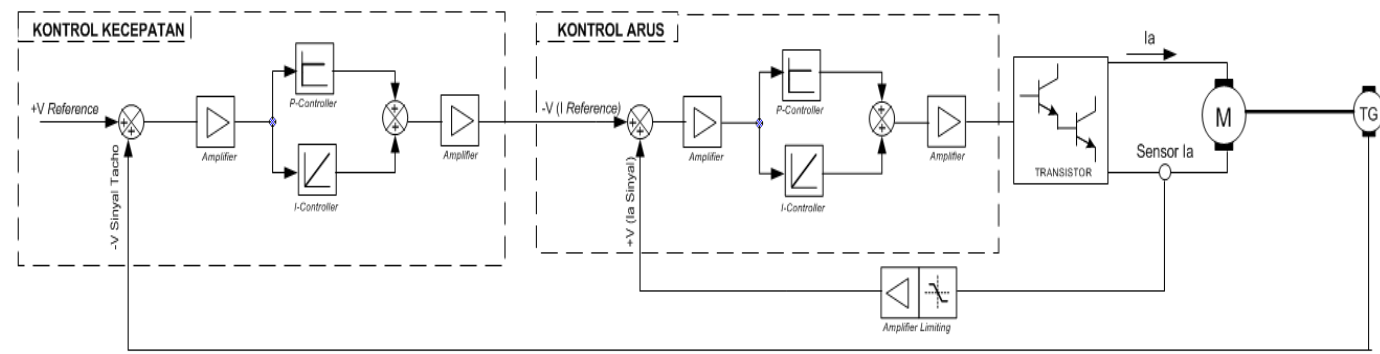

Gambar 6 Diagram blok sistem kontrol torsi motor DC penguat terpisah

Diagram blok Gambar 6 ini menggunakan dua variabel yang akan dikontrol yaitu, variabel kecepatan dan variabel arus. Inti dari sistem kontrol torsi adalah mempertahankan nilai arus motor dengan cara pembatasan nilai arus motor.

Pembuatan sistem kontrol kecepatan akan direalisasikan dengan rangkaian op-amp. Terlihat pada Gambar 7 menunjukkan sebuah sistem kontrol kecepatan yang dibuat dari IC Op-amp 741. KONTROL KECEPATAN

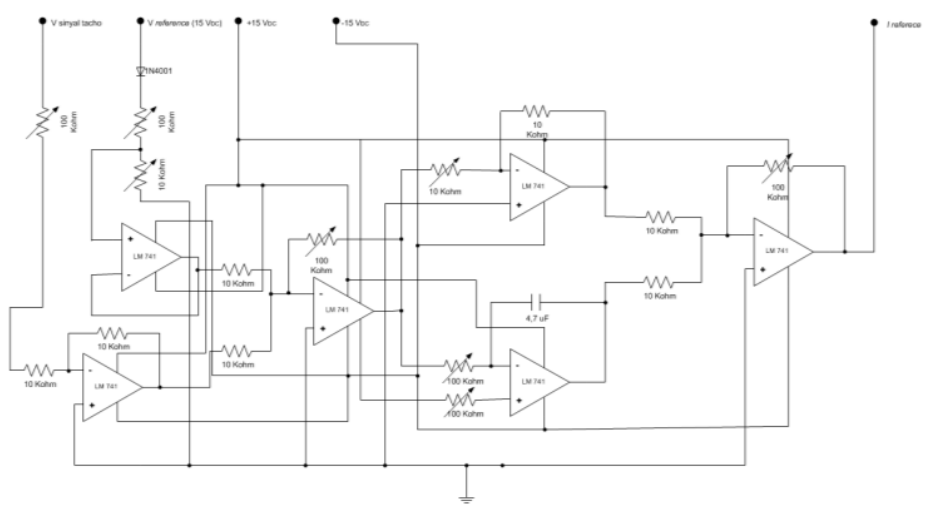

Gambar 7 Rancangan sistem kontrol kecepatan

Rangkaian kontrol kecepatan terdiri dari rangkaian op-amp penjumlah antara sinyal reference kecepatan dengan polaritas positif dan feedback kecepatan dengan polaritas negatif. Sinyal keluaran berupa sinyal error yang akan diolah oleh PI kontrol yang direalisasikan dalam bentuk op-amp integrator dan penguat pembalik sehingga menghasilkan sinyal keluaran kontrol $\mathrm{P}$ dan sinyal keluaran kontrol I yang akan disatukan atau dijumlahkan dengan op-amp penjumlah. Begitu juga dengan realisasi kontrol arus menggunakan prinsip yang sama dengan sistem kontrol kecepatan. Berikut Gambar 8 menunjukkan sistem kontrol arus dengan IC op-amp 741.

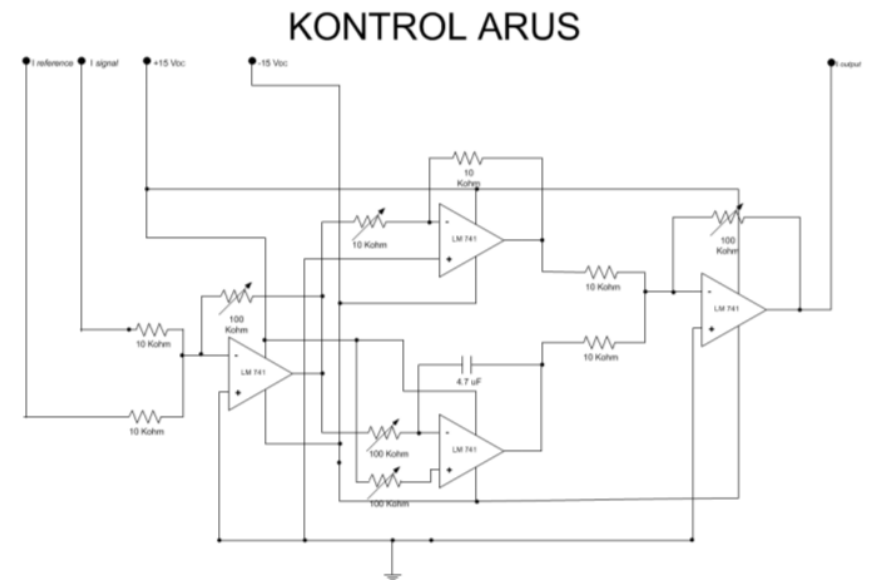


Gambar 8 Rancangan sistem kontrol arus

Inilah inti dari sistem kontrol torsi berdasarkan prinsip persamaan nilai torsi motor sebanding dengan nilai arus armaturnya sehingga kontrol kecepatan hanya sebagai pemberi arus reference saja. Hasil keluaran sinyal tegangan output sistem kontrol ini harus dikonversi menjadi nilai arus yang akan mengontrol arus armaturnya sehingga perubahan nilai tegangan yang dikeluarkan sistem kontrol sebanding dengan perubahan nilai arus armaturnya.. Rangkaian ini juga sebagai konversi nilai tegangan menjadi nilai arus. Berikut rangkaianya pada Gambar 9.

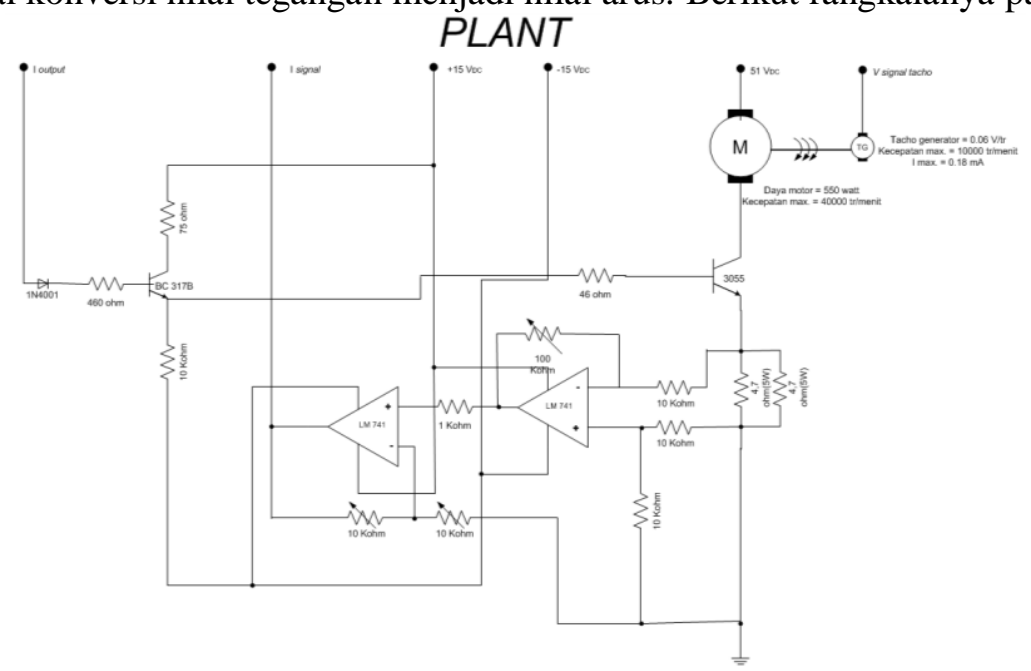

Gambar 9 Rancangan penguat sinyal kontrol dan sensor arus

\subsection{Perancangan Motor DC Penguat Terpisah}

Penelitian ini fokus pada objek motor DC penguat terpisah. Untuk itu, motor bor listrik AC universal harus dimodifikasi menjadi motor DC penguat terpisah. Untuk lebih jelasnya, kita bisa perhatikan pada Gambar 10 merupakan gambar modifikasi motor bor AC. Gambar A pada Gambar 10 ialah rangkaian motor bor AC universal satu fasa sebelum dimodifikasi sedangkan Gambar B pada Gambar 10 ialah hasil modifikasi menjadi motor DC penguuat terpisah
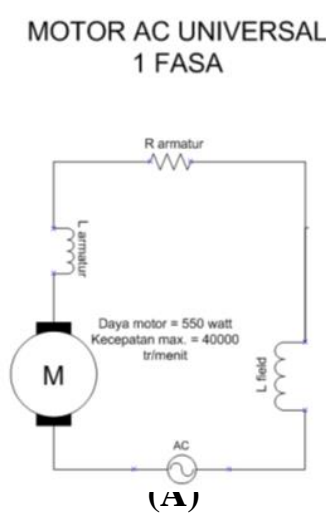

Gambar 10 Rangkaian modifikasi motor bor AC
MOTOR DC PENGUAT TERPISAH



. Untuk konstruksi mekaniknya, tacho generator dipasang sejajar horizontal dengan rotor motor bor tersebut. Rancangan ini ditunjukan pada Gambar 11 


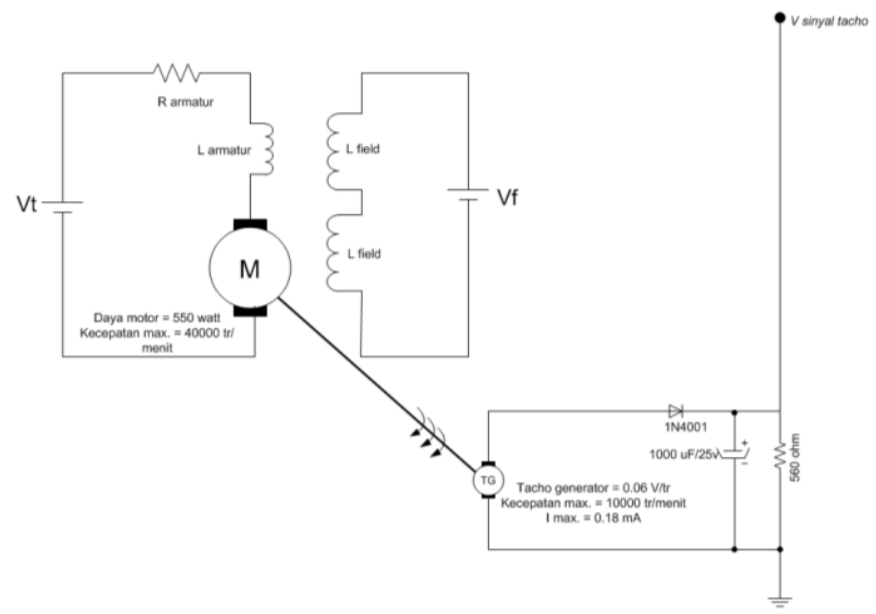

Gambar 11 Rancangan motor DC penguat terpisah dan tacho generator

\section{HASIL DAN PEMBAHASAN}

Berdasarkan hasil implementasi pada konstruksi motor bor yang telah terpasang tacho generator, didapatkan hasil karakteristik motor pada Tabel 1.

Tabel 1 Karakteristik motor DC penguat terpisah

\begin{tabular}{|l|l|c|}
\hline Tegangan Armatur $\left(\mathrm{V}_{\mathrm{T}}\right)$ & $:$ & $54 \mathrm{VDC}$ \\
\hline Tegangan Field $\left(\mathrm{V}_{\mathrm{f}}\right)$ & $:$ & $8,3 \mathrm{VDC}$ \\
\hline Arus Armatur $\left(\mathrm{I}_{\mathrm{a}}\right)$ & $:$ & $0,62 \mathrm{~A}$ \\
\hline Arus Field $\left(\mathrm{I}_{\mathrm{f}}\right)$ & $:$ & $0,44 \mathrm{~A}$ \\
\hline Hambatan Armatur $\left(\mathrm{R}_{\mathrm{a}}\right)$ & $:$ & $14,2 \Omega$ \\
\hline Hambatan Field $\left(\mathrm{R}_{\mathrm{f}}\right)$ & $:$ & $18 \Omega$ \\
\hline Tegangan Tacho $\left(\mathrm{V}_{\text {tacho }}\right)$ & $:$ & $13 \mathrm{VDC}$ \\
\hline Kecepatan motor $\left(\mathrm{n}_{\text {tacho }}\right)$ & $:$ & $216,6 \mathrm{rpm}$ \\
\hline
\end{tabular}

Hasil data Tabel 1 didapat dengan kondisi tanpa beban pada rotor tacho dan pemilihan tegangan armatur maksimum sedangkan pemilihan tegangan field dipilih tegangan minimum pada label trafo step down. Berdasarkan data karakteristik Tabel 1, dengan perumusan kecepatan motor kita bisa menentukan konstanta kecepatan motor ini. Sehingga nilai rata-rata konstanta (c) untuk motor DC penguat terpisah ialah 0,442. Sehingga persamaan kecepatan motor DC penguat terpisah menjadi persamaan (11).

$\mathrm{n}=\underline{\mathrm{V}}_{\underline{\mathrm{T}}}-\mathrm{I}_{\underline{\mathrm{A}}} \cdot(14,2 \Omega)$

\subsection{Pengujian Torsi Motor}

Nilai torsi yang dihasilkan oleh motor DC ditentukan dengan nilai konstanta torsi motor. Untuk itu, kita harus menentukan nilai konstanta torsi motor dengan cara membuat lengan beban yang dipasang pada rotor motor seperti terlihat pada Gambar 12. 


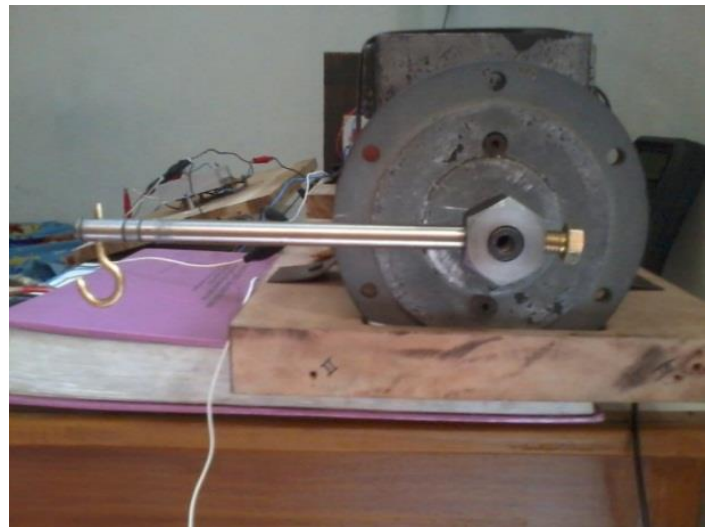

Gambar 12 Konstruksi lengan beban pada rotor (tampak depan)

Dengan asumsi nilai momen kopel lengan beban yang besarnya sebanding, tetapi arah resultan gayanya berlawanan. Sehingga mencapai titik kesetimbangan antara momen kopel beban dan torsi motor. Data hasil terlihat pada Tabel 2.

Tabel 2 Data simpangan beban $(\mathrm{x})$

\begin{tabular}{|c|c|c|c|}
\hline Beban (gr) & Ia (A) & If $(\mathrm{A})$ & $\mathrm{x}(\mathrm{cm})$ \\
\hline 320 & 1.17 & 0.39 & 12 \\
\hline 320 & 1.175 & 0.39 & 12.9 \\
\hline 320 & 1.17 & 0.38 & 10.5 \\
\hline 640 & 1.17 & 0.375 & 5 \\
\hline 640 & 1.17 & 0.375 & 6 \\
\hline 640 & 1.17 & 0.375 & 5 \\
\hline 960 & 1.735 & 0.34 & 5.9 \\
\hline 960 & 1.72 & 0.34 & 5.1 \\
\hline
\end{tabular}

Pada Tabel 2 merupakan hasil implementasi yang menunjukkan nilai variasi beban mempengaruhi simpangan (x) yang dihasilkan oleh torsi motor. Simpangan (x) ini merupakan nilai jarak perpindahan beban dari posisi awal hingga keadaan setimbang dalam lintasan lingkaran yang diukur terhadap sumbu x. Keadaan setimbang diartikan motor tidak mempu lagi memutarkan beban setelah beban berpindah sebelumnya dari titik awal. Sehingga nilai konstanta bisa didapat dari penurunan persamaan (12).

$\sum \mathrm{M}_{\text {beban }}=\sum \tau_{\text {efektif motor }}$

$\left(\mathrm{W}_{\text {lengan beban }} \cdot 0.5 \cdot \mathrm{X}\right)+\left(\mathrm{W}_{\text {beban }} \cdot \mathrm{X}\right)=\mathrm{k} \cdot \mathrm{I}_{\mathrm{f}} \cdot \mathrm{I}_{\mathrm{A}}$

Dengan persamaan (13) kita bisa menentukan nilai tetapan torsi efektif motor. Hasilnya dapat dilihat pada Tabel 3. Sehingga didapat nilai tetapan torsi motor efektif sebesar $0.918 \mathrm{NmA}^{-2}$. Sehingga kita bisa menentukan hubungan nilai torsi dengan arus armaturnya. 
Tabel 3 Data torsi efektif motor

\begin{tabular}{|c|c|c|c|}
\hline $\begin{array}{c}\text { Beban } \\
(\mathrm{gr})\end{array}$ & $\mathrm{I}_{\mathrm{A}(\mathrm{A})}$ & $\mathrm{I}_{\mathrm{f}(\mathrm{A})}$ & $\begin{array}{c}\mathrm{T} \\
(\mathrm{Nm})\end{array}$ \\
\hline 620 & 0.595 & 0.420 & 0.229 \\
\hline 940 & 0.615 & 0.420 & 0.237 \\
\hline 1260 & 0.655 & 0.420 & 0.253 \\
\hline 1580 & 0.665 & 0.420 & 0.256 \\
\hline 1930 & 0.675 & 0.420 & 0.260 \\
\hline 2280 & 0.720 & 0.420 & 0.278 \\
\hline 2600 & 0.745 & 0.420 & 0.287 \\
\hline 2950 & 0.760 & 0.420 & 0.293 \\
\hline 3340 & 0.775 & 0.420 & 0.299 \\
\hline 3690 & 0.800 & 0.420 & 0.308 \\
\hline
\end{tabular}

Pada Tabel 3 terlihat adanya perbedaan ketika nilai arus armatur berubah meningkat, nilai torsi efektif juga meningkat. Ini membuktikan adanya nilai yang berbanding lurus. Hal ini ditunjukan juga pada Gambar 13 yang menunjukkan hasil grafik antara torsi dan arus armatur.

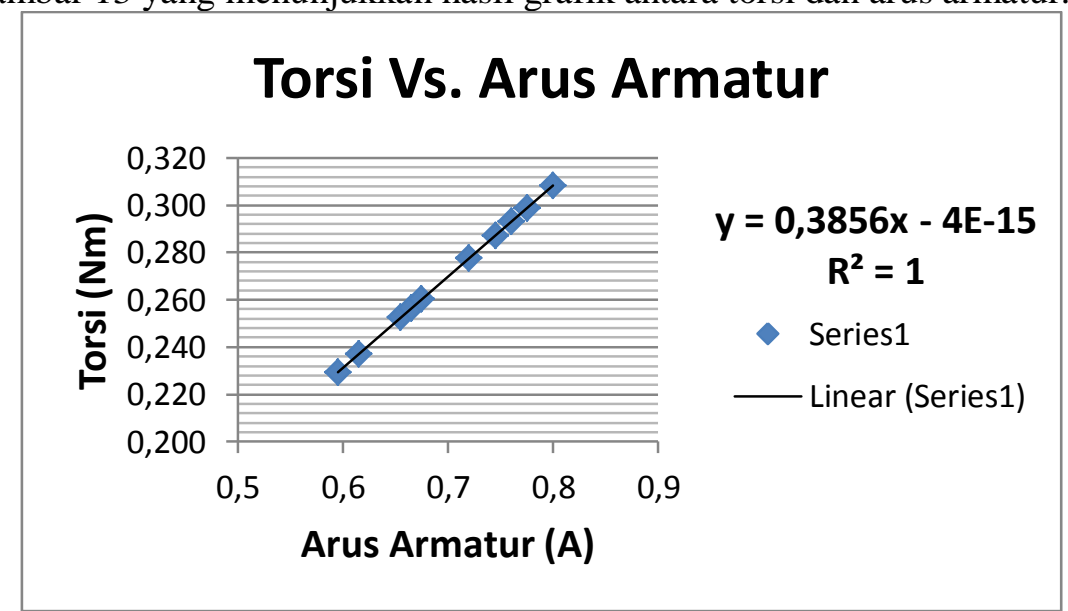

Gambar 13 Grafik torsi efektif vs. arus armatur

Dari hubungan antara torsi motor dan arus armaturnya didapat persamaan dari Gambar 13 tersebut. Sehingga kita bisa menentukan nilai torsi motor (y) berdasarkan nilai arus reference (x) dengan persamaan (14).

$x=\frac{y+4 .\left(10^{-15}\right)}{0.3856}$

Kemudian untuk menguji bahwa hasil sistem kontrol torsi ini bekerja, kita melakukan pengujian torsi terhadap variasi beban. Berdasarkan hasil pengamatan motor akan berjalan pada arus reference bernilai $0,45 \mathrm{~A}$. Kemudian nilai torsi efektif yang dapat dikontrol, maksimum pada arus reference 0,63 A karena beban uji maksimum yang disediakan sebagai beban rotor motor.terbatas yaitu 3690 gram. Oleh karena itu, kita bisa melihat sistem kontrol torsi bekerja baik pada arus reference 0,45 A - 0,63 A. Berikut hasil pengujianya pada Gambar 14 . 




Gambar 14 Grafik pengujian torsi terhadap variasi beban

Dari Gambar 14 tersebut terlihat bahwa sistem kontrol torsi bekerja sesuai dengan yang diharapkan dengan berprinsip bahwa dengan mengendalikan arus armatur, secara otomatis kita mengendalikan torsi efektif motor.

\subsection{Pengujian Kontrol PI}

Dengan menggunakan metode osilasi Ziegler-Nichols kita bisa mendapatkan grafik optimum. Untuk itu, kita mengambil tiga sampel grafik optimum dengan acuan metode osilasi Ziegler-Nichols. Pertama, stabilkan sinyal kontrol kecepatan dengan cara mencari nilai Kp yang dapat membuat sinyal kontrol berosilasi konstan. Berikut hasil sinyal kontrol kecepatan yang sudah memiliki osilasi konstan seperti Gambar 15

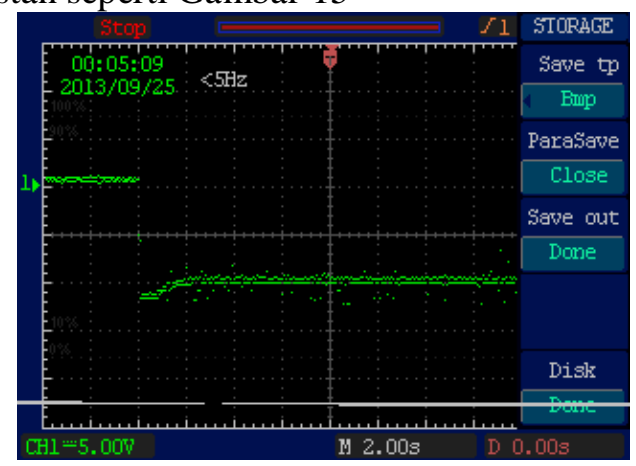

Gambar 15 Grafik sinyal output sistem kontrol kecepatan $(\mathrm{Ki}=21,276$ dan $\mathrm{Kp}=1,667)$

Setelah mendapatkan nilai Kp yang dapat membuat sinyal berosilasi konstan. Selanjutnya kita mengambil tiga sampel grafik yang mendekati grafik optimum.

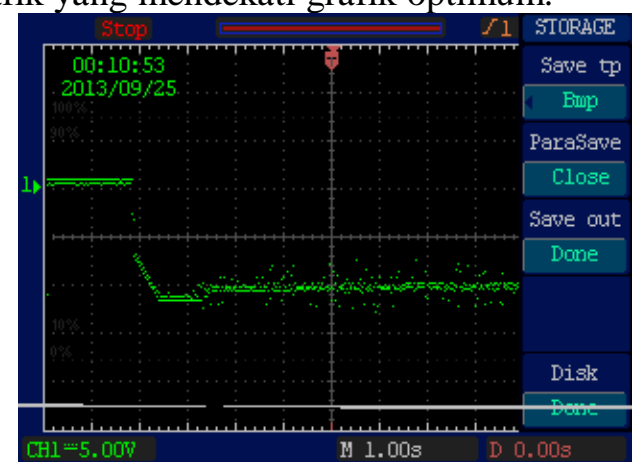

Gambar 16 Grafik sinyal output sistem kontrol kecepatan $(\mathrm{Ki}=2,633$ dan $\mathrm{Kp}=1,667)$ 


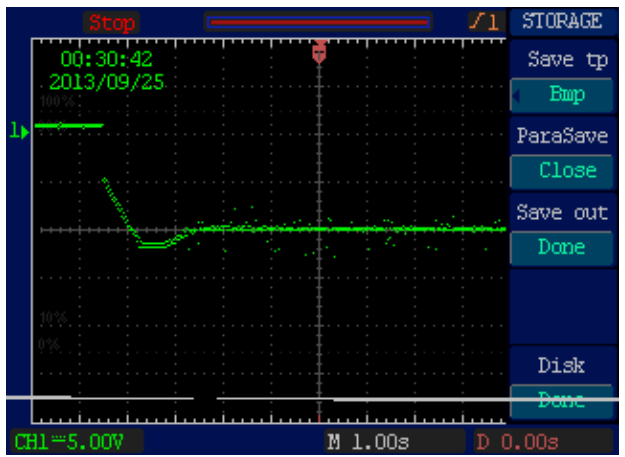

Gambar 17 Grafik sinyal output sistem kontrol kecepatan $(\mathrm{Ki}=2,640$ dan $\mathrm{Kp}=1,042)$

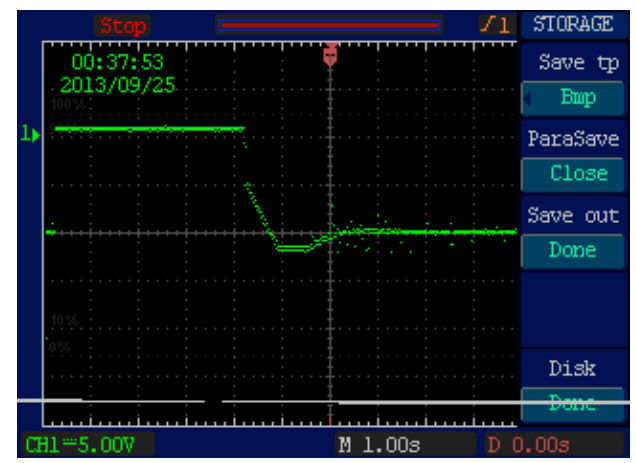

Gambar 18 Grafik sinyal output sistem kontrol kecepatan $(\mathrm{Ki}=3,040$ dan $\mathrm{Kp}=1,053)$

Dari ketiga sampel tersebut, kita memilih grafik optimum berdasarkan nilai settling time cepat, offset minimum, dan nilai overshoot minimum. Kita lihat grafik Gambar 16 terlihat bahwa nilai settling time sekitar 2,2 sekon, nilai offset bisa mencapai 2 volt, dan overshoot sekitar 20\%. Kemudian kita lihat grafik selanjutnya Gambar 17 menunjukkan nilai settling time sekitar 2 sekon, nilai offset bisa mencapai 2 volt, namun osilasi rendah bila dibandingkan grafik Gambar 16. Kemudian nilai overshoot sekitar 25\%. Selanjutnya grafik Gambar 18 terlihat sinyal memiliki nilai settling time sekitar 2,6 sekon, nilai offset sekitar 1 volt - 2 volt, dan overshoot 25\%. Dari hasil pengamatan dan analisis grafik didapat bahwa grafik kedua pada Gambar 17 merupakan grafik terbaik. Karena grafik ini memiliki nilai settling time lebih cepat dibandingkan dua grafik lainnya. Pengambilan grafik optimum kontrol arus juga menggunakan metode yang sama. Gambar 19 merupakan hasil grafik optimumnya.

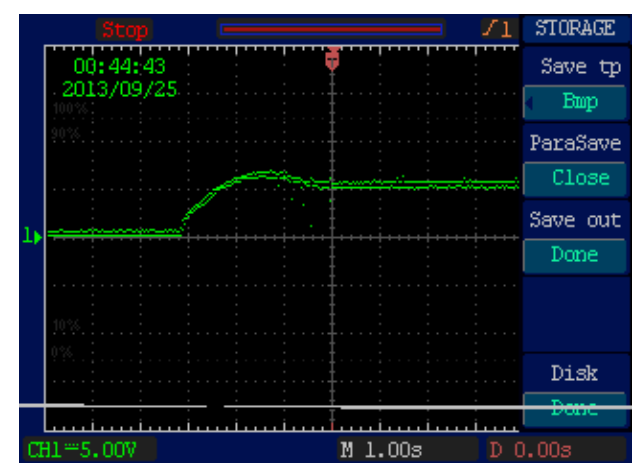

Gambar 19 Grafik sinyal output sistem kontrol arus $(\mathrm{Ki}=2,351$ dan $\mathrm{Kp}=0.117)$

\section{KESIMPULAN}


Dari penelitian yang sudah dilakukan dapat diambil kesimpulan sebagai berikut :

1. Penelitian ini mampu mengimplementasikan sistem kontrol torsi motor DC penguat terpisah.

2. Motor DC penguat terpisah pada penelitian ini memiliki karakteristik nilai tetapan kecepatan motor $(\mathrm{c}=0,442)$ dan tetapan torsi motor $\left(\mathrm{k}=0.918 \mathrm{NmA}^{-2}\right)$.

3. Nilai torsi dapat diatur dari $0-0,243 \mathrm{Nm}$ pada maksimum beban 3690 gram dengan arus nominal $0,8 \mathrm{~A}$.

4. Grafik optimum sinyal kontrol kecepatan berada pada nilai $\mathrm{Ki}=2,640 \mathrm{dan} \mathrm{Kp}=1,042$.

5. Grafik optimum sinyal kontrol arus berada pada nilai $\mathrm{Ki}=2,351$ dan $\mathrm{Kp}=0.117$.

\section{SARAN}

Dalam penelitian ini diharapkan adanya ppengembangan dalam metode percobaan yang lebih baik. Untuk itu, disarankan:

1. Penggunaan alat torsimeter untuk mendapatkan nilai pasti dari torsi motor sehingga data tersebut bisa dijadikan validasi.

2. Simulator dibuat lebih paten sehingga tidak menimbulkan troubleshooting pada rangkaian maupun konsstruksi mekanik yang dapat mempengaruhi hasil pengamatan yang tidak teratur.

3. Pengembangan simulator dalam bentuk digital.

\section{UCAPAN TERIMA KASIH}

Penulis mengucapkan terimakasih kepada Bapak Triyogatama Wahyu Widodo dan Bapak Tri Wahyu Supardi serta pihak - pihak yang telah membantu dan memberiikan saran pada penelitian ini.

\section{DAFTAR PUSTAKA}

[1] Ibrahim, A. W.,_2014, Upgrading Driver Motor DC di Pinch Roll CTCM PT.KS, Krakatau Steel, Cilegon

[2] Frohr, F., 1985, Electronic Control Enginering Made Easy. Siemens Aktiengesellschaft, Berlin dan Munich

[3] Gamayanti, N., 2013, Kontroler Proporsional, http://www.scribd.com/doc/140174192/22Kontroler-Proporsional-P\# diakses pada tanggal 20 Januari 2015

[4] Chairuzzaini, Rusli M., Ariyanto R., 1998, Pengenalan Metode Ziegler-Nichols pada Perancangan Kontroler pada PID, http://elektroindonesia.com/elektro/tutor12.html diakses pada tanggal 3 April 2015

[5] Purnama, A., 2012, Definisi dan Konstruksi Tacho Generator, http://elektronikadasar.web.id/artikel-elektronika/definisi-dan-konstruksi-tacho-generator/ diakses pada tanggal 20 Januari 2015 